\title{
4 Die apartheidsmensbeskouing (skeidingsmodel)
}

Wat hierdie tipe mensbeskouing betref, sal veral klem gelê word op die teologiese en kerklike beskouings wat in die Gereformeerde Kerke in Suid-Afrika (GKSA) na vore gekom het, aangesien dit na my beste wete nog nêrens redelik omvattend beskryf is nie (vgl. Van der Walt, S.J. 1989). Wat die NGK betref, is daar deur voor- en teenstanders reeds breedvoerig daaroor besin. Vroee voorstanders van hierdie mensbeskouing is onder andere te vind by F.G. Badenhorst (1939), J.G. Strydom (1941; 1942), E.P. Groenewald (1947), F.J.M. Potgieter (1956), A.B. du Preez $(1955 ; 1959)$, later by A.P. Treurnicht $(1965 ; 1975)$ en J.D. Vorster (1978). Hierdie mensbeskouing het egter deurlopend skerp kritiek uitgelok en is op teologiese en morele gronde bevraagteken, byvoorbeeld deur B.B. Keet $(1956 ; 1957)$, B.J. Marais (1952), C.F. Beyers Naude en W.D. Jonker, kritiek wat in die tagtigerjare 'n standhoudende stroom boeke tot gevolg gehad het. In hierdie verband kan gedink word aan W.P. Esterhuyse (1979;1982), A.J. Botha (1986), J.C. Marais (1986), J. Kinghom (1986;1990), J.A. Loubser (1987), F. Deist (1991). Uit die geledere van swart teoloë word gedink aan publikasies van A. Boesak (1977), L.R.L. Ntoane (1983), T.A. Mofokeng (1983) en S.P. Govender (1987). Later $(1986 ; 1990)$ sou die NGK hom veel kritieser teenoor apartheid uitspreek.

Waarop egter in hierdie bespreking van die apartheidsmensbeskouing gekonsentreer gaan word, is die vraag of die Gereformeerde teoloë en die GKSA ook 'n slagoffer van hierdie separatistiese mensbeskouing was. Watter beeld vertoon die 'Calvinisme' binne die Gerefonneerde teologie en kerke? Was teoloë soos J.D. du Toit, P.J.S. de Klerk, W.J. Snyman en 'n filosoof soos H.G. Stoker deur die apartheidsdenke beinvloed? Is Hexham (1981:24) korrek in sy beskouing dat die aandeel van die Doppers veel groter was as wat algemeen gedink word en dat J.D. du Toit as vader van die apartheidsgedagte gesien moet word? (vgl. Botha, 1986:139-141, 152-154). (Volgens Willem de Klerk (1980:23) het die Calvinisme immers "die sterkste invloed op Afrikaneridentiteit uitgeoefen".) Is Berkhof (1985:135) korrek in sy oordeel dat in Suid-Afrika geen twee-ryke-leer heers nie maar 'n gereformeerde pseudo-teokrasie, waarin nie, soos Calvyn beoog het, die vrye kerk aan die vrye staat die gebod van God profeties voorhou nie, maar waarin kerk en staat deur dieselfde nasionalisties-rassistiese ideologie beheers word en mekaar die bal toespeel?

Dit is ' $n$ boeiende vraag waar die apartheidsmensbeskouing vandaan kom en wie die vader van die gedagte was (vgl. Botha, 1986:125-145). Hang dit saam met die Christelik-nasionale gedagte, met burgerlike godsdiens (Moody); met 'n dogmatiese ideologie (Ritner); kom dit van die Doppers en die Neo-Calvinisme 
(Hexham) of is dit van puriteinse oorsprong (W.A. de Klerk)? Is die apartheidsbekouing van Calvinistiese of eerder van nasionalistiese oorsprong (A.J. Botha)? Groei dit vanuit ' $n$ bepaalde antropologie (Kinghorn, 1990)? Moet hier eerder van ideologiese Calvinisme gepraat word (Snyman, 1985)? Daar bestaan by sommige navorsers konsensus dat die oorsprong van hierdie tipe denke gesoek moet word in die rigting van die piëtisme (A. Murray), Neo-Calvinisme (Kuyper) en romantisisme (Fichte) (Botha, 1982:41-43; Bosch, 1984:25-32; Durand, 1985: 39 e.v.; vgl. De Gruchy, 1991:21-29). Sonder twyfel het ons hier met 'n komplekse verskynsel te doen (Giliomee \& Schlemmer, 1989:40-62). Daarby moet ook nie vergeet word nie dat apartheid 'n bepaalde ewolusie deurgemaak het ( $V$ an Jaarsveld, 1979:1-23).

Ook kan die vraag gevra word of J.D. du Toit (Totius) die vader van apartheid was en of hy die eerste was om in 1944 "'n uitgewerkte Skriftuurlike onderbou aan apartheid te gee" (Botha, 1986:140, 153)? Sy voordrag verteenwoordig immers ' $n$ wegbeweeg van 'n pragmatiese na 'n meer prinsipiële apartheid (Botha, 1986:192-194). Of was die vader van apartheid dalk N. Diederichs wat met sy Fichteaanse sienings in Nasionalisme as lewensbeskouing en sy verhouding tot internasionalisme (1936) die cornerstone van apartheid gevorm het (De Klerk, 1976:203)? Vir Diederichs was die wese van mens-wees immers deel-van-' $n$ nasie-wees.

Sonder die opheffende, veredelende en verrykende invloed van hierdie hoogste omvattende eenheid wat ons nasie noem, kan die mens nooit die volle hoogte van mens-wees bereik nie. Eers deur sy toewyding tot, sy liefde vir en sy diens aan die nasie kan die mens kom tot die alsydige en harmoniese ontwikkeling van sy volle persoonlikheid. Eers in die nasie as die totaalste, omvattendste menslike gemeenskap kan die mens homself ten volle verwenselik (Diederichs, 1936:17-18).

'n Verdere moontlikheid is dat G. Cronje die vader van apartheid was, soos trouens by geleentheid deur homself erken is (vgl. Die Burger (1980-01-11) en verder Cronje, 1945, 1947, 1948).

Wie sal ooit weet waar en hoe dit alles begin het, en deur wie (vgl. Van Wyk, 1986a:2-3). Moet ons nie dalk sê dat rassisme as mensbeskouing basies en tipies is van élke mens en dat dit net na geskikte geleenthede en bevoordelende omstandighede soek om te ontkiem en te groei nie? Behoort ons nie met Wentsel (1987: $644,646)$ saam te stem nie as hy opmerk dat "het racisme is diep geworteld in de mens" en dat "de racist en onderdrukker zit in kiem in ieder mens"?

Wanneer ons vervolgens na enkele wetenskaplikes uit die GKSA gaan kyk, moet noodwendig 'n seleksie gemaak word. Die feit dat hier nie dieper ingegaan word op die standpunte van byvoorbeeld W. Postma (vgl. Hexham, 1981:180; Botha, 
1986:141; Heyns, 1989:99), J.V. Coetzee (1935) en J.C. Coetzee (1965, 1983) nie, beteken geensins dat hulle in lierdie verband onbelangrik was (of is) nie.

\subsection{J.D. du Toit (1877-1953) - Totius}

Van Totius word beweer, so het ons reeds gehoor, dat hy in 1944 die eerste was om "'n sistematiese uitleg van die Skrif (te) bied ter ondersteuning van apartheid"; hy "kombineer Skrifuitleg met 'n volksfilosofiese werklikheidsbegrip en 'n geskiedenisleer op die patroon van Kuyperiaanse geskiedskrywing" (Kinghom, 1986: 101). Van verskillende kante sou daar kritiek teen Totius se politieke beskouings ingebring word (vgl. Bosch, 1984:26 e.v.; Botha, 1986:155 e.v.; De Gruchy, 1979:32; De Gruchy, 1984:106-114; vgl. ook Van Wyk, 1989b:26-27; Heyns, 1989:103, 107).

Dat Totius ' $n$ apartis was, is sonder meer duidelik indien sy politieke perspektiewe nagegaan word (Du Toit, 1977). Hy was téén gelykstelling en verbastering (1977:337, 352) en het, saam met ds. J.G. Strydom, vir die handhawing van 'n streng apartheid gepleit (1977:367). Trouens, Totius (1977:365-368) het in 1943 entoesiasties melding gemaak van die studie van Strydom oor Die rassevraagstuk en die toekoms van die blankes in Suid-Afrika (uitgegee deur die NGK in die OVS) en hy verwys hiema as 'n "uitnemende brosjure" (Du Toit, 1977:339). So verwys Totius (Du Toit, 1977:364,365) in 1949 ook na G. Cronje se Voogdyskap en apartheid (1948) as 'n "uitnemende geskrif" en ' $n$ "meesterlike prestasie". Ook die ander boek van G. Cronje, naamlik Regverdige rasse-apartheid (1947) is deur Totius (1977:371-374) met groot entoesiasme begroet. Veral die studie van E.P. Groencwald hierin word aangeprys as "een van die beste uiteensettinge" en "van buitengewone betekenis" (1977:372). In hierdie studie van Groenewald terloops een van die mees ekstreme uiteensettings ten gunste van apartheid waarvan ek kennis dra - betoog hy dat nasionale, sosiale en godsdienstige apartheid die wil van die Here is. Groenewald (in Cronje, 1947:65) konkludeer dat "die beleid van apartheid en voogdyskap soos deur die Christelike Afrikaner voorgestaan ten opsigte van die nie-blankes, teruggevoer kan word tot die Woord van God."

Van buitengewone belang is Totius se voordrag voor die volkskongres van 1944 waarin hy gehandel het oor "Die godsdienstige grondslag van ons rassebeleid" (Du Toit, 1977:330-343) - 'n standpunt wat hy, volgens sy seun S. du Toit, tot sy einde in 1953 gehandhaaf het (Du Toit \& Du Toit, 1955:3). In hierdie voordrag neem hy sy vertrekpunt in die Godsleer. Hy betoog dat God die groot Skeidingmaker is, by die skepping (Du Toit, 1977:330-331), by Babel (Du Toit, 1977: 332-333) en by Israel (Du Toit, 1977:339). Die Christendom, sê hy, wil nie verskille uitwis nie, maar heilig (Du Toit, 1977:353) - 'n (Thomistiese) standpunt oor natuur en genade wat deurgaans by hierdie problematiek ' $n$ groot rol gespeel het. 
'n Swaar aksent word gelê op die voorsienigheid (Du Toit, 1977:331, 333, 337) en raad van God (Du Toit, 1977:337) by die ontstaan van nasies (Hand. 17:26). Die Bybel leer die pluriformiteit van nasies terwyl "die hoëre eenheid in Christus geleë en geestelik van aard is" (vgl. Kol. 3:11; Gal. 3:28) (Du Toit, 1977:337, 333-334). Verder stel hy dit dat ons wel dankbaar moet wees dat slawerny afgeskaf is - "hier het die Christelike beginsel deurgewerk" - maar dit beteken nie dat (die beginsel van) "onderhorigheid" hiermee afgeskaf is nie: "voogdyskap" oor "naturelle" is blywend (Du Toit, 1977:341); die gekleurdes moet deur Christus vrygemaak word, "dan sal hulle nie strewe na rewolusionêre verandering van aardse omstandighede nie" (Du Toit, 1977:342). Die afleiding kan gemaak word dat Totius van mening was dat die 'Christelike beginsel' hiér nie moet deurwerk nie.

Wat in hierdie voordrag opval, afgesien van sy teologiese regverdiging van apartheid, is dat Totius baie min direk na Kuyper verwys (slegs een keer), terwyl hy baie noue aansluiting vind by standpunte van twee NGK predikante, naamlik Badenhorst en Strydom - sy aansluiting by die studie van Badenhorst van 1939 maak hom dus nie die eerste sistematikus van apartheid nie; dit is trouens besonder opvallend dat in die genoemde studies van A.J. Botha (1986), J. Kinghorn (1986), J.C. Marais (1986) en J.A. Loubser (1987) geen vermelding van Badenhorst in die bronnelys gemaak word nie. Die voorsienigheid van God, wat feitlik geïdentifiseer word met dit wat in die wêreld gebeur, word by Totius besonder sterk beklemtoon, veel sterker in elk geval as die Christologie. Van die reikwydte van die versoening in Christus word niks gesê nie. Waar die Christologie (en ekklesiologie) ter sprake kom, word dit gespiritualiseer en 'geïdealiseer': die eenheid in Christus is slegs 'geestelik' (en dus onsigbaar) - terwyl ons weet dat die Bybelse spreke oor 'geestelik' tog baie duidelik met die leiding van die Heilige Gees in verband gebring word. Hierdie standpunt van 'n geestelik / onsigbare eenheid leef vandag nog sterk in die NHKA maar is deur die GKSA, veral op inisiatief van W.J. Snyman, laat vaar. Dit val ook op dat die skeidingsprinsipe wat deur Totius hanteer word, ánders as dié van die bevrydingsteoloë van vandag met 'n Marxisties-ekonomiese onderskeiding van ryk-arm, 'n politiekrassistiese onderskeiding van swart-wit is, sodat die vraag ontstaan waarom hy hom nie van die voor die hand liggende Bybels-teologiese onderskeiding van geloof-ongeloof bedien het nie (ten minste wat die kérk betref). Was dit omdat sy politieke vooroordele hom hierin mislei het? Of was dit omdat sy oorlogservarings gedurende die Tweede Anglo-Boereoorlog (D'Assonville, 1977: 22-32) en sy stryd in die volkslewe (D'Assonville, 1977:105-111) so 'n groot invloed op hom gehad het? Die opvallende is dat sowel die onderskatting van die politieke dimensie (die pietisme van A. Murray) as die oorskatting daarvan (die nasionalisme van Totius) tot dieselfde resultaat lei, naamlik 'n verabsolutering van die volk.

Baie kortliks wil ons in hierdie verband aandag gee aan die siening van $\mathrm{S}$. du Toit (1905-1982), seun van Totius, vir die grootste deel van sy professoraat verant- 
woordelik vir die Ou-Testamentiese opleiding aan die Teologiese Skool Potchefstroom (TSP) gedurende die tydperk 1936-1970. In sy studie oor die "Openbaringslig op die apartheidsvraagstuk" van 1949 sluit Du Toit (1955:22-34) baie nou by sy vader aan. "Die Calvinis besef dat as die Boerevolk ondergaan, dit uit is met die Christelike beskawing in hierdie land en dat ook die kerk sal verdwyn" (Du Toit, 1955:33). Sy studie van 1959 oor "Die Heilige Skrif en rasseverhoudinge" verskil opmerklik in toonaard van die vorige. In die 1959-studie oordeel Du Toit dat ras- en volkevermening nie per se sonde hoef te wees nie hoewel dit onder sekere omstandighede wel die geval kan wees (Du Toit, 1959:13). Daar was syns insiens op daardie stadium geen ander beleid as "eiesoortige ontwikkeling" moontlik nie - 'n beleid wat voogdyskap voorlopig nog kon insluit, maar wat dan 'n beleid sou wees wat groot offers gaan vra (Du Toit, 1959:18). Onder alle omstandighede mag nooit vergeet word nie dat God meer is as 'n volk, ja, 'n volk kan "selfs ondergaan as die eer van God dit eis" (Du Toit, 1963:139).

\subsection{P.J.S. de Klerk (1895 - 1971)}

'n Tweede teoloog wat vermelding verdien en iemand wat ook baie sterk deur die Kuyperiaanse teologie beinvloed was, is P.J.S. de Klerk, wat vanaf 1949-1961 professor in Dogmatiek aan die Teologiese Skool Potchefstroom was. Hy was sekerlik nie van dieselfde statuur as Totius nie, maar hy was op 'n stadium die mees bedrewe publisis in die GKSA en daar het talle boeke uit sy pen gevloei. Sy werk was nie altyd van oorspronklike gehalte nie - vergelyk byvoorbeeld sy Woorde en dade van Jesus met J.H. Bavinck se Geschiedenis der Godsopenbaring: Het Nieuwe Testament; tog het hy vanweë sy talle publikasies, waaronder sy bekende katkisasieleerboek, Handboek Gewyde Geskiedenis, wat talle herdrukke beleef het, 'n wye invloed uitgeoefen. Daarby was De Klerk 'n groot sendingentoesias en ook lank by sendingorganisasie betrokke.

Sy proefskrif Kerk en sending in Suid-Afrika (1923), verwerf aan die Vrije Universiteit van Amsterdam, was wat die sénding betref rigtinggewend vir sy tyd, maar helaas nie ten opsigte van kerklike en politieke verhoudings nie. De Klerk oordeel dat om aan die naturelle-vraagstuk deur middel van die sending toon aan te gee, "dit noodsaaklik sal wees om hier dan konsekwent deur te voer die skeiding van swart en blank, 'n standpunt wat die kerke reeds in die verlede aangehang het" (De Klerk 1923:165). Die enigste oplossing hier is, so gaan hy voort (vgl. De Klerk, 1923:165-169), om "die rasse kerklik sowel as maatskaplık te segregeer". Die teorie van "die ekwaliste, van volkome gelykstelling, gaan nie op nie, dit juis was die groot onheil van Suid-Afrika". Die sending moet rekening hou met die rasse-onderskeid en die Christendom bring nie sosiale gelykheid nie. "Die naturelle tog behoort tot 'n laer ras". Die Skepper het self die lyne getrek en "die enigste standpunt is segregasie van blank en swart op kerklike en maatskaplike gebied". Hierdie siening moet uitloop op die stigting van "nasionale 
kerke". Galasiërs 3:28 kan nie hierteen aangevoer word nie, want daar gaan dit om "die hoëre eenheid in Christus". Stelling XIV van die proefskrif lui dat 'segregasie van blank en swart, sowel op kerklike as op maatskaplike gebied, kom die sending in Suid-Afrika ten goede'.

De Klerk sou hierdie gedagtes in 'n hele reeks kleiner geskrifte voortsit en nader uitwerk ten opsigte van die sending, onderwys, huwelik en politiek.

Sending moet gesegregeerd wees, voer hy aan (De Klerk, 1935:121-128). Natuurlik, "wie teen die sending is, is teen die Skrif en is geen Calvinis meer nie", maar God het die grenslyne tussen rasse daargestel en dit moet eerbiedig word (De Klerk, 1937:127). Daar word gevra of Kuyper dan nie self gewys het op die onderskeid tussen Nederlander en Javaan en dat elk 'n eie vorm van lied, gebed en belydenis sal hê nie (De Klerk, 1935:127)? "Eie nasionale naturelle-kerke" is nodig (De Klerk, 1935:127). "Om prinsipiële redes, gegrond in die Calvinisme van ons volk, is dit dus nodig dat daar op sendingsgebied segregasie van wit en swart sal wees" (De Klerk, 1935:127). Sending dood nie 'n volk se eie nasionaliteit nie - dus is segregasie vir goeie sending noodsaaklik, ondanks die feit dat in Jesus se optrede teenoor die Samaritaanse vrou (Luk. 4; Joh. 4) "die eerste skeidsmuur tussen Jood en heiden wegval" (De Klerk, 1965:247).

Volgens De Klerk moet daar ook wat die onderwys betref, streng gehou word "aan segregasie van blank en swart" (De Klerk, 1934:3). Aparte skole is nodig want die naturelle se "behoeftes is heeltemal anders" (De Klerk, 1934:3). Swart kulture moet immers nie vernietig word nie maar moet deur die evangelie "geheilig" word (De Klerk, 1934:2,6). Die teologiese argument is duidelik: die genade hef nie die natuur op nie maar heilig dit.

letwat breedvoeriger moet aan die aspek van (rasgemengde) huwelike aandag gegee word aangesien dit 'n goeie illustrasie bied van die styl en gehalte van (teologiese of ideologiese?) argumentasie. Hoewel De Klerk stel dat hy nie oor kerklik-gemengde nie maar wel oor rasgemengde huwelike gaan handel, beroep hy hom nogtans op die Ou- en Nuwe-Testamentiese verbod teen godsdiensgemengde huwelike (De Klerk, 1939:56-57).

God het gewil dat elke volk in die geskiedenis van die mensheid sy besondere taak sal hê. Daarom moet ons die skeidslyne wat God daar gestel het tussen die rasse dan ook as goddelike ordinansie respekteer (De Klerk, 1939:56).

(Die feit dat die (wit èn bruin) Afrikaners uit vermenging ontstaan het, word egter geïgnoreer.) Ook die onderskeid tussen "hoëre beskaafde Christenvolke en laere natuurvolke" word na vore gehaal. 
Al word sekere persone uit die laere natuurvolke Christene, dan mag hulle daardeur nog nie deur gemengde huwelike ingelyf word in die geledere van die hoëre beskaafde Christenvolke nie. Die swart rasse dink swart ... Daar is nou eenmaal grenslyne deur die Skepper daargestel wat ons nie in die gees van Babel se toringbou maar kan wegredeneer nie. Daar is nasionale eienaardighede by naturelle en gekleurdes wat nooit deur ' $n$ huwelik opgesmelt kan word in 'n blanke beskawing nie. Dis moeilik om ' $n$ gekleurde ras van 'n lae peil te verstaan en in 'n huwelik met 'n hoëre kultuurras te laat saamwoon. Die twee rasse lewe geestelik en persoonlik in aparte wêrelde. En hierby kom nog dat die swarte en gekleurde rasse in ons land onbekwaam is om hulle in die beskaafde lewe te beweeg. Daarom moet sulke gemengde huwelike gedurig 'n bron van morele korrupsie wees (De Klerk, 1939:57).

Voorts word daarop gewys dat die drie Hollandse (Afrikaanse) kerke in ons land geweier het om sulke gemengde huwelike kerklik te bevestig.

Die Christendom bring geen sosiale of kerklike gelykheid teweeg nie. Gelykstelling lei tot verlaging van beide rasse. Gemengde huwelike tussen hoëre beskaafde en gekerstende volke met laer rasse druis in teen Gods Woord, en is ' $n$ vergryping aan die goddelike ordinansies vir die huwelik. Dis niks minder as ' $n$ misdaad nie, veral as ons let op die skerp grenslyne tussen die rasse in ons eie vaderland ... Daarom eis die eer van ons volk dit dat sulke misdadige huwelike deur wetgewing gestraf sal word, anders gee ons ons eer en ons verlede prys (De Klerk, 1939:58).

In sy politieke oorwegings gee De Klerk (1953:44-49) 'n teoretiese uiteensetting van die hoofmomente van 'n Calvinistiese politiek - die soewereiniteit van God, die owerheid as dienaar van God, soewereiniteit in eie kring, burgerlike vryheid en die reg tot verset - aspekte wat heelwat instemming sal wegdra. Ook staatsabsolutisme en 'n magstaat word verwerp (De Klerk, 1953:55-56). Maar waarom, sou gevra kon word, word hierdie temas nie ook vrugbaar gemaak ten opsigte van swart vryheid en Afrikaner-volksabsolutisme nie? Sou die ideologie van apartisme hier ' $n$ verblindende effek uitgeoefen het? Lê sieleheil en volksheil dalk nog te veel op een vlak (vgl. De Klerk, 1937:69).

\subsection{W.J. Snyman (1899-1981)}

'n Derde teoloog waaraan ons aandag wil bestee, is W.J. Snyman, professor in Nuwe Testament aan die TSP vanaf 1946-1970. Wat die basiese aspekte van die apartheidsbeskouing betref, sit Snyman die denklyn van sy voorgangers voort, hoewel hy op een uiters belangrike punt - die ekklesiologie - 'n deurbraak maak wat verreikende konsekwensies sou meebring. 
Oor Snyman se standpunt het ek reeds eerder in 'n ander verband geskryf (Van Wyk, 1985) en ek maak hier samevattend van daardie gegewens gebruik vir sover dit ter sake is.

\section{* Eksegese en 'eisegese'}

Eerstens die vraag na eksegese en eisegese. Snyman het vanuit die staanspoor besonder baie aandag bestee aan die eksegese van relevante Skrifgegewens. In dié verband moet onthou word dat sy denke die sinodebesluite van die GKSA oor volkeverhoudings vanaf 1961-1967 wesenlik beïnvloed het. Wanneer hierdie gegewens nagegaan word (vgl. onder andere Snyman, 1977:284-321; Snyman et al., 1969:11-34), is daar bitter min van Kuyper terug te vind. (Waar Snyman wél by Kuyper aangesluit het, was dit ten opsigte van die onderskeiding kerk as instituut en kerk as organisme (Snyman, 1977:34,138).) Hierdie sterk punt eksegese - was waarskynlik ook die swak punt vanweë Snyman se selektiewe omgang met die Skrif. In sy eksegese het hy byvoorbeeld nooit aandag gegee het aan die universele reikwydte van die versoening in Christus en die implikasies daarvan vir die samelewing nie. Sy Skrifberoep verraai 'n sekere mate van vooringenomenheid, ' $n$ beroep waarin apartheid apriories aanvaar is en daarna na 'n teologiese fundering daarvan gesoek is. Snyman het nie krities genoeg na sy vooronderstellings gekyk nie.

\section{* Natuur en genade}

Tweedens die vraag na die verhouding tussen natuur en genade - 'n deurlopende motief, so het ons reeds by Totius en De Klerk opgemerk. Die kerk elimineer nie die die volk nie, sê Snyman, dit heilig dit; in die kerk word wel sondige teenstellings opgehef maar nie die natuurlike onderskeidings nie (Snyman, 1977:285, 312). Dit is egter ' $n$ ope vraag of hierdie Thomistiese onderskeiding in die Gereformeerde teologie op verantwoorde wyse hanteer is. Die verhouding tussen natuur en genade is nie heeltemal so eenvoudig en so ontspanne as wat Thomas dit geformuleer het nie (Noordmans, 1986:428-451; Theron, 1988:157171). Wat Suid-Afrika betref, staan ons voor die verstommende feit dat die Rooms-Katolieke Kerk vir 'n integrasiemodel en die Gereformeerde Kerke (aanvanklik altans) vir 'n segregasiemodel gekies het!

\section{* Die onderskeiding: ras en volk}

Derdens kan ons daarop wys dat Snyman vanuit die staanspoor tussen ras en volk onderskei het en aandag daarvoor gevra het dat ons nie van 'n rassevraagstuk nie maar van 'n volkevraagstuk moet praat. Daarmee wou hy doelbewus van die gevaar van rassisme wegbeweeg, maar of hy hiermee ' $n$ genoegsame ope oog vir die gevaar van etnosentrisme (nasionalisme) gehad het, is 'n ander vraag. Sy 
denke het immers basies binne die denkraamwerk van apartheid beweeg, al het hy sekere modifikasies daarop aangebring.

\section{* Die verband tussen land en volk}

Vierdens het hy aandag gevra vir die noue verband tussen land en volk. "Die verband tussen land en volk is so nou dat ' $n$ volk moeilik gedink kan word sonder 'n land" (Snyman, 1977:322; vgl. 310, 323, 359, 362, 390, 401). Hierdie verband tussen land en volk was vir hom byna ' $n$ onbetwisbare beginsel waarop hy voortdurend teruggekom het. Volgens Snyman het hierdie verband in Suid-Afrika eenvoudig aparte lande vir aparte volke beteken en dus ' $n$ wegbeweeg van alle vorme van oorheersing (Snyman, 1977:290,411). Snyman was 'n fel teenstander van alle vorme van imperialisme, dus ook Afrikanerimperialisme. Tog roep hierdie standpunt van elke-volk-in-sy-eie-land onnoemlik veel vrae op. Moet hierdie (Bybelse) beginsel wêreldwyd toegepas word? Hóé kan dit ooit in SuidAfrika met sy plurale en vervlegte bevolkingsamestelling gerealiseer word, in elk geval sonder diskriminasie? Is dit werklik so onbybels en so problematies dat verskillende volke in dieselfde land woon? Is die krag van die evangelie (en die bydrae van die kerk ) nie groot genoeg om dit moontlik te maak nie, veral as $77 \%$ van die bevolking beweer dat hulle Christene is? Is mense en volke (ook polities) onversoenbaar? Kan verskillende volke nie een 'nasie' vorm nie?

\section{* Die terme Christelik en nasionaal}

Vyfdens het Snyman ook uitdruklik oor die terme Christelik en nasionaal gehandel en wel in die verbinding van Christelik-nasionaal. Nou is dit waar dat die $\mathrm{CN}$-gedagte, veral CNO (Botha, 1982:37), baie sterk in die GKSA gefigureer het. Snyman het ook sy jeugjare in 'n omgewing deurgebring, die Noordoos-Kaap, meer spesifiek Steynsburg, waar hierdie gedagte besonder sterk geleef het. (Die ontstaan van die Potchefstroomse Universiteit vir Christelike Hoër Onderwys is 'n lewende bewys van die vervulling van die CNO-ideaal.) Snyman probeer sy CNideaal deur 'n hele reeks voorwaardes teen verwording afskerm. Volksbelange, sê hy, mag nooit voor kerk- en koninkryksbelange inskuif nie (Snyman, 1977: 220-221, 331-334, 345); die Christelike gaan voorop en nie die nasionale nie en wel só dat die Christelike bepalend is vir die nasionale en nooit omgekeerd nie (Snyman, 1977:340). Voortdurend moet daarteen gewaak word dat die nasionale "onchristelik" en selfs "anti-Clristelik" kan word (Snyman, 1977:337). Hoe goed ook al bedoel, het die $\mathrm{CN}$-motief later - vanweë 'n hele reeks teologiese, historiese en politikologiese besware - onder skerp kritiek gekom (vgl. Van Wyk, 1991:245-252; Botha, 1982, Van der Walt, 1978/88:242-252). Die alternatief vir die $\mathrm{CN}$-gedagte word vandag veel meer in die rigting van die perspektief van die koninkryk van God gesoek. 


\section{* Eenheid en verskeidenheid}

Sesdens kan gelet word op Snyman se hantering van die begrippe eenheid en verskeidenheid. Wat die kerkleer betref, aanvaar hy, volgens sy volkerekerk-konsep, die verskeidenheid van gemeentes (= plaaslike kerke) (Snyman, 1977:112, 287), maar nie die verskeurdheid nie wat hy as sónde bestempel (Snyman, 1977 . 454). Hierdie verskeidenheid funksioneer egter bínne die eenheid, want anders sou dit op kerklike verskeurdheid neerkom. Die verskeidenheid mag nie absoluut wees nie; die eenheid van gemeentes moet sigbaar tot openbaring kom en wel in een algemene sinode wat álle (Gereformeerde) gemeentes insluit (Snyman, 1977: 85). Hiermee het Snyman die apartheidsdenke van sy voorgangers deurbreek, altans sover dit die kérk betref, nog presieser: sover dit kerkvergáderings betref. Dat hy hierin nie ver genoeg gegaan het nie en slegs sinodale eenheid in plaas van, en selfs ten koste van, plaaslike gemeentelike eenheid beklemtoon het, is waar. Terugskouend besef ons vandag dat dit te min is en dat aan etnisiteit nog te veel gewig verleen is. (Die algemene sinode is saamgestel uit etnies-gestruktureerde nasionale sinodes.) Indien ons egter sy standpunt beskou teen die agtergrond van die hoogbloei van die apartheidsdenke in die vyftiger- en sestigerjare van hierdie eeu, kan daar meer waardering vir sy standpunt betuig word en kan dit in 'n sekere sin selfs as epogmakend beskryf word.

Snyman het ook die verskeidenheid van vólke erken maar nagelaat om die vraag na 'n moontlike eenheid in hierdie opsig ter sprake te bring. Die vraag dring homself na vore of die kerk nie hier vir volke as model kon dien van hoe eenheid-inverskeidenheid gerealiseer kan word, van die moontlikheid van meer volke-ineen-land/nasie (om vir 'n oomblik die terme volk en nasie in hierdie betekenisnuanse te gebruik)?

Snyman het doelbewus by die 'Calvinisme' aansluiting probeer vind (Snyman, 1977:346-347, 352-356). Hiervolgens mag die Christelike godsdiens nie geïndividualiseer of geprivatiseer word nie maar raak dit die die gánse lewe (Snyman, 1977:341, 344) - die vólle lewe moet onder die heerskappy van Christus staan (Snyman, 1977:128). Snyman was 'n 'man van die derde weg' wat telkens gepoog het om tussen twee uiterstes deur te stuur, tussen liberalisme en konserwatisme, tussen ' $n$ apartheidsteologie en 'n integrasieteologie (Snyman, 1977:378-381, 418). Dat hierdie pogings die gevaar van 'n balansteologie met hom meegebring het en dat daarmee ' $n$ sekere mate aan radikaliteit (in die goeie sin van die woord) ingeboet is, is waar. Tog moet ons konkludeer dat, hoewel Snyman se volks- en mensbeskouings basies binne die apartheidsparadigma beweeg het, hy een van die eerstes was wat hierdie paradigma op 'n belangrike punt deurbreek het. 


\subsection{H.G. Stoker (1899-1993)}

'n Volgende persoon aan wie ons hier aandag wil bestee, is die internasionaal bekende Potchefstroomse filosoof H.G. Stoker.

Teen Stoker se beskouings is daar die afgelope jare baie skerp kritiek ingebring (vgl. Van Wyk, 1991:397-398). Bax (s.j.:32-33) kritiseer Stoker se volksbeskouing as onskriftuurlik, oncalvinisties en romanties. Kuiper (1986:76-77) meen dat Stoker foutiewelik uit Kuyper se standpunt van soewereiniteit in eie kring afgelei het dat ook 'n vólk 'n eie kring is, iets wat Kuyper nooit gedoen het nie, en voorts dat die Afrikanervolk nie soewerein in eie kring opgetree het nie maar totalitêr ten opsigte van die hele samelewing (vgl. Durand, 1985:42). Dieselfde kritiek is ook by De Gruchy $(1979: 32 ; 1984: 110)$ te vind, terwyl hy byvoeg dat Stoker se volksbeskouing neerkom op "a civil religion based on a doctrine of creation". Hierdie kritiek kom ook by ander skrywers voor (Moody, 1975:66-67; Botha, 1986:139-141, 152-154) sodat die suggestie gemaak word dat die veelgeroemde studies oor Koers in die krisis van die laat dertiger en vroeë veertigerjare eerder as koersloosheid in die krisis getipeer moet word (Ritner) (vgl. Snyman, 1985: 131; Botha, 1986:136, 173 e.v.). Ntoane (1983:33-34) bring Stoker (en Heyns) selfs met ' $n$ verwórde Calvinisme in verband. Ntoane (1983:253) is van oordeel dat die teologie van Calvyn "as an instrument in Black liberation struggle" kan dien.

Stoker wou doelbewus by Calvinistiese gesigspunte aansluit soos onder andere sy brosjure Praktiese Calvinisme van 1956 getuig. Hy (1970:293) beskou die volk, soos die kerk, as 'n "samelewingsverband", as 'n "sosiale kring" en dus ook as "soewerein in eie kring" (Stoker, 1933:34 e.v.; Stoker, 1941:228-234; Stoker, 1961:128; Stoker, 1970:287). God het 'n verskeidenheid van volke gewil (1941: $222,250 ; 1967: 326)$ en daarom kan Stoker ('n goed gedefinieerde) apartheid verdedig (1967:212-216). "Ons segregasiebeleid", sê hy, "rus op 'n Calvinistiese rasseleer" (1941:157). Die bloedband is 'n "prinsipiële bepaling" vir die volk en die landsband 'n praktiese vereiste (1941:146).

Dit is duidelik dat Stoker met sy Wysbegeerte van die Skeppingsidee 'n swaar aksent op die skcpping gelê het en dit is 'n ope vraag of hy nie die spreke van God in die skepping (en geskiedenis) oorspan het ten koste van die spreke van God in die Skrif nie. ' $n$ Verdere vraag is of hy nie die natuuropenbaring en die Skrifopenbaring (te) los van mekaar hanteer het nie sodat elkeen 'n eie lewe begin lei het. Calvyn wou juis die verband tussen die twee sterk vashou deur die natuuropenbaring in die lig van (deur die bril van) die Godsopenbaring te lees. 'n Voorbeeld van hoe sterk die skeppingsidee by Stoker funksioneer, is daarin te vind dat hy poog om die mens nie vanuit die sonde nie, en ook nie vanuit Christus nie, maar vanuit die orde van die skepping te ondersoek, dit wil sê die mens soos 
hy vandag is, afgesien van die sonde (1967:92-93). Van teologiese kant word daarop gewys dat ons vandag geen ander mens ken as die sóndige mens nie (Berkhof, 1973:198; König, 1990:108) sodat dit vrugteloos is om na 'n mens te soek afgesien van die sonde. Miskien moet hier bygevoeg word: ons ken ook verlóste sondaars!

Die kritiek van Ntoane op Stoker, naamlik van 'n verworde Calvinisme, en wel aan die hand van een klein artikel van Stoker wat in 'n gemeenteblad verskyn het, is wat wetenskaplike gehalte betref uiters teleurstellend - selfs ook wat sy vergelyking van Calvyn en Heyns betref (vgl. Van Wyk, 1984a:49-51). Ntoane is slagoffer - iets wat so dikwels ook by wit teoloë aangetref word - van sy eie vooronderstelling, naamlik dat Stoker (en Heyns) (vanweë hulle Afrikanerskap?) noodwendig oncalvinisties móét wees.

Dit is egter duidelik dat Stoker, ondanks (of danksy?) sy 'Calvinisme', steeds binne die denkraamwerk van die apartheidsparadigna beweeg het.

\subsection{L.J. du Plessis (1897-1968)}

Teen apartheid en die apartheidsmensbeskouing het daar geleidelik - van vroeg af - kritiek ontwikkel, kritiek wat met die loop van jare toegeneem het. Van die vroegste kritici was twee wetenskaplikes van die PU vir CHO, te wete L.J. du Plessis en J.H. Coetzee. Later sou hierdie kritiek verder gevoer word deur onder andere W.J. de Klerk (1971, 1980, 1984), J.M. Vorster (1984), M. Wiechers (1988), L.M. du Plessis (1988) en T. Eloff (1988), terwyl die boek Altyd reformeer (1985), onder redaksie van myself en J.M. Vorster, ook binne hierdie konteks gelees moet word (vgl. Van der Walt, 1993).

Wat die apartheidsmensbeskouing betref, wil ek voorts kortliks aandag vra vir die bydrae van L.J. du Plessis. Hy was een van die eerste persone wat die totale onhoudbaarheid van dr. D.F. Malan se slagkreet ('Glo in jou God, glo in jou volk, glo in jouself') ontmasker het: "Ek glo nie soos wyle dr. Malan in my God, my volk en myself nie, maar alleen en uitsluitend in God Almagtig, deur Jesus Christus onse Here" (vgl. Woord en Daad, Junie 1970:9). Reeds in 'n vroee stadium van sy denke sê hy nie onvoorwaardelik ja vir apartheid nie maar ja-nee (1957).

Dit alles beteken nie dat Du Plessis, aanvanklik altans, grondig deur die apartheidsdenke beïnvloed was nie. Van sy vroegste artikels, soos byvoorbeeld dié in Koers in die krisis (Du Plessis, 1935:263-272), wat gehandel het oor liberalistiese en Calvinistiese "naturelle-politiek" (vgl. Du Plessis, 1940:221-234), is hiervan 'n sprekende bewys (vgl. ook Du Plessis, 1959:256-263). Later sou hy hom veel kritieser uitspreek, 'n houding wat selfs op 'n hewige botsing met dr. H.F. Verwoerd uitgeloop het (Potgieter, 1976:206). So het hy in 1960 gewaarsku 
"teen die dodelike gevare van Verwoerdisme" (Potgieter, 1981:24) en dat dit tot 'n ramp vir Suid-Afrika kan lei. Hy het hom heftig verset teen die beginsel en praktyk van blanke baasskap (Potgieter, 1976:221, 222; Potgieter, 1981:25) en hy wou baasskap met broederskap vervang (Potgieter, 1976:224) en blanke imperialisme met 'n multi-nasionale federalisme (Potgieter, 1976:225, 240).

Dit alles beteken nie dat hy teen die beleid van tuislandontwikkeling gekant was nie, maar hy het aanvaar dat dit alleen nie die probleme van Suid-Afrika sou oplos nie. Die beleid van baasskap moes vervang word met 'n beleid van politieke selfbeskikking vir die 'Bantoe' en gepaste medeseggenskap in SuidAfrika as geheel (Potgieter, 1976:222). Die volgende uitspraak van Du Plessis illustreer die gedagte:

Aan die groepies ontstamde Bantoe, wat geen ander tuiste sal hê as blank Suid-Afrika nie, en aan die Kleurlinge en Indiërs sal uiteindelik volle burgerreg in die blanke staat gegee moet word, maar nie voordat blank SuidAfrika oorwegend blank sal wees nie" (Potgieter, 1976:225).

Volgens Potgieter $(1976: 241,244)$ het Du Plessis nie (blanke) identiteit nie maar roepingsvervulling as die norm vir die Afrikaanse volkslewe beskou. Sy besondere bydrae moet in die volgende gesoek word: sy aksent op die roepingsgedagte, sy siening van 'n verruimde Afrikanerskap, sy teenkanting teen blanke baasskap, sy visie op 'n Suid-Afrikaanse federasie en die rol wat Suid-Afrika in Afrika moet speel (Potgieter, 1976:251). ${ }^{6}$

Terugskouend besef ons vandag dat Du Plessis nog ryklik deur die apartheidsgedagte beinnvloed was, maar aan die ander kant is dit ook duidelik dat hy hierdie denke op enkele kempunte deurbreek het - sodanig dat dit hom in die sestigerjare in skerp botsing met die Nasionale Party gebring het.

\subsection{Sinodale besluite GKSA}

Dit is die moeite werd om oorsigtelik aan die vraag aandag te gee of die apartheidsmensbeskouing ook in die sinodale besluite van die GKSA gereflekteer word. In hierdie besinning sal veral aksent gelê word op besluite in verband met maatskaplik-staatkundige verhoudings, hoewel kerklike verhoudings vanselfsprekend nie buite rekening gelaat sal word nie (vgl. Van Wyk, 1979:102-113; Van Wyk, 1988:16-32).

6 Dit is insiggewend om op te merk dat dic huidige staatspresident, mnr F W de Klerk, in die vyftigerjare 'n regsstudent by L.J. du Plessis was 
In die heel vroegste besluite, 10 jaar na die ontstaan van die Gereformeerde Kerke in 1859, en 79 jaar voor die triomf van die apartheidsideologie in 1948, en dus vóórdat die invloed van Kuyper (1837-1920) enigsins noemenswaardig kon wees, besluit die Sinode van 1869 (Acta, 1969:24) dat gelykstelling "nu nog" ongeskik en onmoontlik is. In 1873 (Acta, 1873:32-33) word 'gelykstelling' gedefinieer as Woord- en sakramentsbediening aan blankes en gekleurdes in dieselfde kerkgebou, terwyl herhaal word dat gelykstelling ongepas en ondoenlik is. Dit is 'n studie op homself om te probeer nagaan wat die verste oorsprong en diepste wortels van hierdie besluite was en of dit deur die bekende - en omstrede - 1857-besluit van die Ned. Geref. Kerk (in verband met die "swakke broeders") beïnvloed was. (Maar reeds eerder, in 1824, het die Ned. Geref. Kerk besluit dat die sakramente apart aan swartes bedien moet word, Landman, 1991:34). Wat vasstaan, is dat die NGK en die GKSA 'n eeu en 'n kwart gelede ongeveer dieselfde standpunt oor kerklike apartheid ingeneem het - met dié van die NGK waarskynlik nog ietwat soepeler. Juis rondom hierdie saak, naamlik dié van kerklike eenheid, het daar twee skeurings in die Gereformeerde Kerke plaasgevind (Bethulie gedurende 1877 en Humpata gedurende 1908). As daar dan 90 jaar later in 1958 besluit word dat vermenging op kerklike terrein "ongeoorloof" is omdat dit die gevaar inhou van ondermyning van die nasionale identiteit en roeping van veral die getalswakkere blankes (Acta, 1958:266, 268-270), dan is dit net ' $n$ voortsetting van die besluit van 1869. In 1942 is selfs die verstommende besluit geneem waarin die Sinode ter sterkste protesteer teen die voorgenome bewapening van "Nieblankes", want dit is "volksgevaarlik, in stryd met ons Christelike tradisies en druis in teen ons sendingbeleid" (Acta, 1942:30).

Die jare 1961-1967 verteenwoordig 'n nuwe tydperk in die sinodale besinning en die invloed van W.J. Snyman is besonder opvallend. In 'n groot mate bied die sinodale besluite ' $n$ weergawe van sy standpunt van volkerekerke (die gelowiges in 'n volk is die ware volk en die kerk word volksgewys gestruktureer). Die natuur-genade-denkskema speel deurgaans 'n belangrike rol: die genade hef die natuur nie op nie, die kerk dus nie die volk nie (vgl. Acta, 1961:112). Vir die eerste maal vind ons nou 'n afgeronde reeks besluite oor persoonlike, kerklike en maatskaplik-staatkundige verhoudings. Die rol wat etnisiteit speel, is deurgaans duidelik sigbaar, soos blyk uit die standpunt ten gunste van afsonderlike eredienste, kerkinstituering (Acta, 1961:119), nasionale sinodes (Acta, 1964:268; 1967:188) en teologiese skole (Acta, 1961:177; 1964:265). Op een punt, egter, word die apartheidsdenke deurbreek, naamlik ten opsigte van kerkvergaderings: Hiervolgens behoort één algemene sinode uit die vier nasionale sinodes (oorwegend etnies gestruktureer) saamgestel te word, 'n 'gemengde' sinode dus, wat inderdaad ook sedert 1965 met vergaderings begin het. Aksenturering van hierdie sinodale eenheid, selfs aangevul met kontak op klassis-vlak (Acta, 1970:361), het egter geskied ten koste van die eenheid op die vlak van die plaaslike gemeente en het as gevolg daarvan (tereg) veel kritiek opgeroep. 
Die groot vraag is egter hoe oor die maatskaplik-staatkundige verhoudings geoordeel is. Dit is uit die besluite duidelik dat die Sinodes voorkeur gegee het aan die volkstaatgedagte (elke volk in sy eie land) en dat selfs die voogdyskapbeginsel gunstig bejeën is (Acta, 1967:187-188). (Die opmerking van Spoelstra (1991: 200) dat die GKSA die eerste was om die kolonialistiese beginsel van voogdyskap 'af te wys', is nie korrek nie aangesien dié beginsel tot vandag toe deel vorm van die besluite van die GKSA.) In 1970 is selfs besluit dat "van kerkweë 'n beleid van gebiedskeiding bevorder word", ' $n$ besluit wat (gelukkig) in 1985 herroep is (Acta, 1985:431-432). In 1985 is die volkstaatgedagte versag met die besluit dat waar

... ' $n$ toestand van algehele gebiedskeiding ... nie moontlik is nie, word ' $n$ besonder groot verantwoordelikheid op volke en bevolkingsgroepe geplaas om onderling in 'n gesindheid van vrede, vryheid, versoening en geregtigheid saam te lewe, sodat die regte van minderhede eerbieding word en oorheersing uitgeskakel word (Acta, 1985:444).

Veral sedert 1970 tree daar egter ' $n$ aanmerklike aksentverskil in, en selfs méér as dit, en word daar veel minder aksent op etnisiteit en verskeidenheid en meer klem op die eenheid van die kerk gelê. Hierdie vernuwing word teweeggebring vanwee die adviese wat vanaf die Gereformeerde Ekumeniese Sinode (GES) op die sinodes begin dien het. So word besluit dat ras, volk of kleur nie die kriteria vir kerklidmaatskap (en erediensbywoning) mag wees nie en dat teen niemand op grond daarvan gediskrimineer mag word nie (Acta, 1985:437, 650). 'n Hoogtepunt van hierdie besluite, komende uit 'n minderheidsrapport wat die agt deputate van die GKSA by die GES Harare in 1988 ingedien het en deur die Sinode GKSA van 1991 aanvaar is, is die volgende: Die Sinode verklaar dat

the ideology of apartheid, which is a political and social system by which human dignity is adversely affected and whereby one particular group is detrimentally suppressed by another, cannot be accepted on Christian grounds because it contravenes the very essence of reconciliation, neighbourly love and righteousness, the unity of the Church and inevitably the human dignity of all involved and is therefore a sin and the biblical justification of it is a heresy (Acta, 1991:160, 169; vgl. 187).

Dit is duidelik dat daar verskille is tussen die besluite van 1869-1958 én die van 1961-1967, soos wat daar ook verskille is tussen die besluite van 1961-1967 en die van 1970-1991. Die besluite verskil in strekking en inhoud en daar bestaan spanning tussen hulle, selfs weersprekings.

\subsection{Kritiek op die GKSA}

Vanuit die sogenaamde jonger Gereformeerde Kerke het daar veral van C.T. Rabali kritiek na vore gekom. Hy oordeel dat die Suid-Afrikaanse gereformeerde 
teologie "misrepresented the Bible's message and that of the Reformed tradition with regard to man ... It implicitly denied the Bible's message concerning all people as being made by God in his image" (Rabali, 1989:16; vgl. 1986:88-94). Hy konkludeer dat veel van die Suid-Afrikaanse swart teologie as waarlik gereformeerde teologie kan deurgaan "while much that has been going under the name of Reformed theology will be found to have been a deformation of the Reformed theology" (Rabali, 1989:18).

Van kerklike kant het daar veral sedert die tagtigerjare kritiek van Sinodes Suidland, Soutpansberg en Middellande (Sinodes SSM) na vore gekom. Ek wil hier veral verwys na die besluite van Sinode Middellande in 1983 te Metsi-A-Matala waarin etnisiteit as kriterium vir gemeentevorming, kerkvergaderings en teologiese opleiding afgewys is. Dié Sinode beskou dit as 'n geloof-plusstandpunt (geloof-plus-etnisiteit) en gevolglik as 'n afbuiging van die reformatoriese belydenis van die sola fide (Acta Middellande, 1983:76). Al drie Sinodes SSM het die "Konsensus van Nooitgedacht" van 1986 aanvaar en die feit dat Sinode Potchefstroom hierdie Konsensus in 1988 indirek (vanweë 'n minderheidsrapport) nie met genoeg aandag bejeën het nie, het groot spanning tussen die vier nasionale sinodes laat ontstaan. (Hierdie standpunt is gelukkig in 1991 verander - Acta, 1991:207-210.) In hierdie Konsensus, wat die gespreksresultate van deputate uit die vier sinodes bevat, is die eenheid van die kerk beklemtoon en etnisiteit gerelativeer. Gedurende 1990 en 1991 het die vier deputategroepe hulle gesprekke oor tussenkerklike en staatkundige verhoudings op 'n hoopvolle wyse voortgesit en die drade van Nooitgedacht weer opgetel. Nooitgedacht 1986 het vir die GKSA ongeveer dieselfde betekenis as wat Cottesloe 1960 vir die NGK gehad het.

Afgesien van die kritiek wat voortdurend vanuit die GES na vore gekom het - en die GKSA so van sektarisme bewaar het - het die skerpste kritiek in 1989 van die Christian Reformed Church of North America (CRC) gekom. As gevolg van hierdie kritiek het die CRC sy verhouding met die GKSA tydelik opgeskort (Acta, 1991: 180-182). Die CRC het die besluite van die GKSA noukeurig bestudeer en tot die konklusie gekom dat dit 'twee verskillende ekklesiologieë' bevat, een reeks besluite waarin verskeidenheid beklemtoon word (en etnisiteit prominent figureer) en ' $n$ ander reeks besluite waarin eenheid op die voorgrond staan (hoofsaaklik adviese van die GES wat besluite van die GKSA geword het). In die oë van die CRC kon die GKSA nie duidelike bewyse lewer dat hy nie apartheid handhaaf nie. Die CRC is immers van mening dat apartheid sonde en die teologiese regverdiging daarvan ' $n$ kettery is.

Naas hierdie kérklike kritiek vanuit die binneland en buiteland, kan ook gedink word aan die ernstige kritiek wat met die verloop van tyd deur verskillende teoloë geopper is. Van die vroegste kritiek kan by Buskes (1955) en Verkuyl (1969) 
gevind word, maar daarna sou dit tot 'n magtige koor aangroei. Trouens, daar is geen enkele aan my bekende buitelandse etikus wat hom nie uiters krities teen apartheid uitgelaat het nie. Tiperend hiervan is die uitspraak van Douma (1990:122):

Wat de kerk moet doen, is: Apartheid als kerkelijk, politiek en sociaal systeem krachtig en ondubbelzinnig afwijzen, en - voorzover in haar vermogen ligt - buiten werking stellen.

Volgens Verkuyl $(1969: 98,102)$ is apartheid as ideologie in stryd met die Bybel.

\subsection{Slotopmerkings}

Ten slotte enkele samevattende opmerkings oor die apartheidsmensbeskouing.

\subsubsection{Die invloed van Kuyper en die Neo-Calvinisme}

Dit is ongetwyfeld waar dat Kuyper (s.j. .668) uiters positiewe opmerkings oor die Boere van Transvaal gemaak het (1959:32-33) en minder vleiend oor (die invloed van die algemene genade op) die Afrikamens geskryf het (vgl. Centraal Weekblad, 21-10-1981:1-2). Tog kon hy uiters positief oordeel oor die groot voordele - 'n ontwikkeling - verbonde aan bloedvermenging en het dit ook pertinent met die Calvinisme in verband gebring (Kuyper, 1959:27-31). Kuyper (1959:52) was ook fel gekant teen enige volkskerkgedagte.

Die vraag is of Kuyper se sienings, veral ten opsigte van die soewereiniteit van God, soewereiniteit in eie kring en algemene genade (vgl. Duvenage, 1962:225238), afgesien van sy groot positiewe bydrae (Smit, 1989:47), 'n negatiewe uitwerking op Suid-Afrika gehad het. Smit (1989:51-54) kom na 'n noukeurige analise van Kuyper se beskouings tot die gevolgtrekking dat Kuyper geen apartis was nie en dat die volksideologie van die Afrikaner nie sito-sito aan Kuyper toegeskryf kan word nie (vgl. ook Giliomee \& Schlemmer, 1989:43, met verwysing na Gerrit Schutte; Van Wyk, 1991:392). Wél moet gesê word dat Kuyper se dualistiese kerkbeskouing (kerk as instituut en kerk as organisme) en sy verwaarlosing van die profetiese roeping van die kerk as instituut in die samelewing (Van Rooyen, 1964:122-124, 136; vgl. Durand, 1978:26), groot speelnimte gelaat het vir die verwording van 'n politieke beleid. In Suid-Afrika was daar ook geen Christelike politieke party wat hiérdie taak (van die kerk-as-organisme) kon volvoer nie. Myns insiens was die apartheidsidee egter lank voor Kuyper vasgelê en lank voordat dit in ' $n$ apartheidsideologie ontwikkel het. 


\subsubsection{Historiese konteks}

Hier wil ek die ongewone stap doen en na jeugervarings verwys, opgedoen in die Noordoos-Kaapland, wat gewoonlik as die bakermat van die Doppers bekend staan. Ek het my naamlik dikwels die vraag afgevra hoe dit gekom het dat mense 'n apartheidsmensbeskouing kon ontwikkel het. In die Noordoos-Kaap het immers doodgewone mense gebly wat waarskynlik nooit van Fichte gehoor het nie en nie aan ' $n$ bepaalde ideologie, bewustelik altans, verknog was nie. Van Calvyn het hulle kennis gedra, en van Kuyper ook, maar miskien nog meer van die 'ou skrywers'. Lektuur wat hulle gelees het, was Mel, à Brakel, Smijtegelt asook Spurgeon. Hulle politieke sienings is wesentlik deur die twee Anglo-Boereoorloë (en die twee wêreldoorloë) beinvloed. My grootvader aan moederskant, J.P. Kruger (1872-1919), het in die Tweede Anglo-Boere-oorlog vir die Vrystaat geveg, was later ' $n$ krygsgevangene na Ceylon en het twee kinders in konsentrasiekampe verloor; my grootvader aan vaderskant, A.P. van Wyk (1871-1948), was 'n Kaapse rebel. Wat hulle gemeen gehad het, was die stryd teen Britse imperialisme.

Die vraag ontstaan waarom sulke mense - en hulle nasate - vir 'n sisteem van swart onderdrukking sou kies; hulle wat self van die eerste vegters vir vryheid in Afrika was. Vir sover my ervaring strek, het in die noordoostelike gedeelte van die Kaapkolonie, die sogenaamde Nokland, 'n veel sterker anti-Brits as antiswart-gevoel geheers (vgl. Botha, 1982:3,18,25,37; Regehr, 1979:143,144). Brittanje het immers die onaflhanklikheid van die Boere-republieke afgeneem. Hierdie anti-Brits-gevoel moet egter nie verkeerd verstaan word as 'n gevoel teen Engelssprekende persone nie maar as 'n verset teen Britse imperialisme. Die swart mense het binne hierdie konteks ter sprake gekom, veral toe die idee posgevat het dat die Engelssprekendes die swart mense téén Afrikaneridentiteit wou gebruik, of liewer misbruik. (Daarby was die swygsaamheid van die Engelse kerke teen die onderdrukking van die Afrikaners baie opvallend.) Wat onder hierdie Afrikaners geleef het, was die ideaal van ' $n$ vrye volk in ' $n$ vrye land. Terugskouend besef ' $n$ mens egter dat die grens tussen nasionalisme en imperialisme ragfyn is en baie maklik oorskry kan word, soos duidelik blyk uit die Britse imperialisme, die Nederlandse kolonialisme, die Duitse Nasionaal-sosialisme, die Italiaanse Fascisme, die Soviet Kommunisme en - die Afrikaner-apartisme asook Afrika-diktature. Hierdie oorskryding van grense hang saam met die sondige menslike natuur van hoogmoed en etnosentrisme, van magswellus en dominasie, 'n natuur (ook volksnatuur) naamlik wat nie daarin kan slaag om ook aan ander volke se belange te dink nie.

Ek twyfel of die Afrikaners doelbewus vir 'n sisteem van onderdrukking (sou) gekies het. Hulle het waarskynlik gehoop om in Suid-Afrika 'n soort Europese model van soewereine state te kon ontwikkel. Maar wat bedoel was en wat 
gedoen is, is nog nie dieselfde nie (vgl. Esterhuyse, 1982:21,89). Goeie bedoelings (veral as dit eensydig ontwerp is) ontsnap nie outomaties aan die gevaar van immorele implementering daarvan nie. Hulle - (ons) - het in gebreke gebly om betyds te besef dat hierdie ideaal in die Suider-Afrikaanse konteks onmoontlik gerealiseer kan word; in elk geval nie sonder dat die menswaardigheid van swart mense misken en hulle vryheid as volke aangetas sou word nie. Daarby het die Afrikaners nie ' $n$ ope oog gehad vir die sirukturele dimensie van die samelewing nie en is gehoop dat met ' $n$ individuele etiek (dit wil sê goeie interpersoonlike verhoudings) volstaan kan word. Die Afrikaners het nie goed besef dat wat hulle in 1910 met Uniewording geërf het 'n stuk Britse imperialisme was en dat hulle so gou moontlik daarvan ontslae moes raak nie. In plaas daarvan het hulle die imperialisme gekontinueer en dit in 'n nuwe gestalte (apartheid) laat voortbestaan - sodat een van die basiese (en negatiewe) kenmerke van apartheid inderdaad in imperialisme bestaan. Apartheid bestaan nie net uit diskriminasie (teen mense) nie maar ook uit dominasie (oor mense).

\subsubsection{Die apartheidsmensbeskouing is sondig}

Die apartheidsmensbeskouing is inderdaad 'n sóndige mensbeskouing (vgl. Noordegraaf, 1990:34). Dit is natuurlik waar dat daar diegene is wat van mening is dat "die beleid van afsonderlike ontwikkeling moreel ten volle verantwoord is" en dat "geen ander beleid só moreel, só Skrifverantwoord is soos die beleid van afsonderlike ontwikkeling vir die verskeidenheid van volke nie" (Treurnicht, 1975:20); en dit is waar dat dr. A. Hertzog (1969:3983) in sy veelbesproke toespraak in die Parlement oor Calvinisme opgemerk het dat dit die Calvinistiese Afrikaner is wat "homself gered het, en daarby sy Engelssprekende landgenoot en die beskawing gered het". Tog moet ons sê dat die apartheidsmensbeskouing inderdaad sóndig is en dat hiérdie soort Calvinisme gefaal het (Bosch, 1991b:134-135), ondanks die vele sterk punte wat ten gunste daarvan opgenoem sou kon word. Vergelyk Bosch (1991b:130-134) se uiteensetting van die kenmerke van die Calvinisme met dié van Hertzog, 1969:3980-3981). Apartheid is méér as "n eksperiment wat nie gewerk het nie", méér as 'n skip wat op "die harde rotse van ekonomiese realiteite gestrand het" (Heyns, 1989:49), méér as veranderings ter wille van eie voortbestaan, oorlewing en identiteit (Viljoen, 1978:29, 30, 61). Ten diepste spruit dit voort uit 'n onbybelse mensbeskouing (vgl. Kinghorn, 1989:112-129; 1990:105-144). Apartheid veronderstel immers ten eerste onreg, ten tweede gestruktureede onreg en ten derde gelegitimeerde onreg. Apartheid wortel in 'n rassistiese mensbeskouing. Dit gaan uit van menslike ongelykheid in plaas van gelyk(waardig)heid; dit skep verdeeldheid in plaas van eenheid, tweedrag in plaas van versoening; dit maak mense onvry, ja, slawe, in plaas van vry. As sodanig skep apartheid spanning en polarisasie in plaas daarvan dat dit vrede bring; dit diskrimineer in plaas van reg te laat geskied; dit oorbeklemtoon die volk ten koste van die individu en offer die mensbeskouing 
op aan die volksbeskouing. 'n Verdere konsekwensie van apartheid is dat een ras belangriker as ' $n$ ander geag word; apartheid oorbeklemtoon 'n skeppingsteologie ten koste van die Christologie; dit benadruk die voorsieningheid ten koste van die ekklesiologie; dit ag die sonde groter as die genade. Wanneer so ' $n$ visie dan nog teologies onderskraag word, word dit net soveel erger. Wentsel (1987:651-652) oordeel korrek as hy rassisme in stryd ag met die mens as beeld van God, met die eenheid van die mensheid, met die versoening deur Christus, met Christelike ootmoed en met geregtigheid. Hy beskryf eiesoortige ontwikkeling as "een schreeuwende groepzonde" en die teologiese regverdiging daarvan as 'n kettery (Wentsel, 1987:652; vgl. Van Genderen \& Velema, 1992:267, 281-282).

Daarom moet die erkenning van E.P. Groenewald in Die Kerkbode (1992-05-15, p.8-9), al is dit nie ongekwalifiseerd nie ("ek kan nie geheel en al verwerp wat ek gesê het nie"), verwelkom word dat hy destyds "in sekere opsigte mistastings gemaak het" en dat "die uitgangspunt destyds verkeerd was in die sin dat daar nie genoeg tussen kerk en staat onderskei is nie"

Moreel geoordeel moet ons sê dat voortbestaan-in-geregtigheid verkieslik is bo blote voortbestaan (Degenaar, 1976:39, 50, 85, 88; 1980:11, 27, 64, 90-91). Wat ons vandag in Suid-Afrika nodig het, is meer as blote eksistensie, selfs meer as koëksistensie - wat ons nodig het, is proëksistensie (Degenaar, 1976:34 e.v.). In die negentiende eeu was die Afrikaner simbool van vryheid en geregtigheid maar in die twintigste eeu het hy simbool van verslawing geword (Degenaar, 1980: 18, $24,61,83)$. Die tyd het vir die Afrikaner aangebreek om weer te word wat hy was. Tereg is opgemerk dat "die grootste reële vraagstuk in ons land nie is hoe blank en nie-blank apart kan bestaan en apart gehou kan word nie, maar hoe hulle in harmonie kan saam lewe" (Engelbrecht, 1982:71). Samewerking en nie apartheid nie is die wagwoord van die toekoms (Buskes, 1955:288). Geen wonder nie dat rassediskriminerende gesindhede en optredes al as ' $\mathrm{n}$ vorm van "binnelandse terrorisme" bestempel is (Esterhuyse, 1979:64). Verwerping van apartheid is ' $n$ houding van "Bybelse konserwatisme" en die kanonisering van apartheid is "Bybelse teologiese liberalisme" (Engelbrecht, 1982:14; vgl. König, 1988:77-87).

\subsubsection{Wit Teologie}

Enkele opmerkings moet gemaak word oor daardie vorm van Wit Teologie (waarvan daar ten minste drie vorne is: dié van apartheid, diè van die BritsIsrael-beweging en dié van die Gemeente van die Verbondsvolk) ${ }^{7}$ wat eintlik nie meer teologie is nie, selfs nie eers ideologie nie, maar met demonologie in verband gebring moet word omdat die duiwel as "mensemoordenaar" bekend staan

7 Vir meer gegewens $\infty$ hicrdic problematick kan Grcyling (1992) geraadpleeg word 
(Joh. 8:44). Volgens hierdie standpunt word blankheid met saligheid verbind en swartheid met verlorenheid (vgl. Van der Westhuizen, 1984; 1989) - hoewel natuurlik nooit vergeet moet word nie dat die apartheidsteologie óók 'n ekstreme vorm van Wit Teologie is (vgl. Smit, 1982). R. Hayes skryf in 'n boekie SuidAfrika ... Die land oorkant die riviere van Kus (s.j.) in hoofstuk 11 dat "slegs my eie rasgenote my naaste is" en dat "ons blankes in Suid-Afrika God se volk is en dat die anderskleuriges Satan se nageslag is". Karl Liebenberg, 'n lid van die Gemeente van die Verbondsvolk, het in die hof getuig dat "swartmense nie redbare siele het nie en in dié opsig saam met plante en diere geklassifiseer kan word" (vgl. Beeld, 1991-03-21). "As mense nie meer mense is nie" is 'n kettery van 'n nog intenser aard as dié van die apartheidsideologie gebore (vgl. Van Wyk, 1989a:13-14). So 'n beskouing het met die evangelie van God se reddende genade in Christus niks maar dan ook absoluut niks meer te maak nie. God is nie kieskeurig nie en Hy neem uit enige volk die mense aan wat Hom vereer en doen wat reg is (Hand. 10:34-35). Vergóddeliking van die mens is sonde, verdiérliking eweneens.

\subsubsection{Skrifberoep}

Die teologiese regverdiging van 'n dwaling soos apartheid het die besef laat ontstaan dat uiters omsigtig met die Skrifberoep omgegaan moet word en dat Skrifgegewens veral in hulle konteks hanteer moet word (vgl. die Skrifberoep op Hand. 17:26). Afweer van Skrifmishruik mag egter nie tot Skrifonbruik lei nie 'n tendens wat hom al hoe meer voordoen (vgl. Deist, 1991:378-380), en wat, soos die misbruik, eweneens groot gevare met hom meebring. Indien ons die Skrifberoep laat vaar, kom ons in 'n volkome rasionalistiese teologie tereg. Die Skrif móét gebruik word, ook in morele kwessies, ook ten opsigte van die mensbeskouing, maar dan op 'n verantwoorde wyse (vgl. Van Wyk 1989b:51-54, 58). Dit beteken konkreet dat in 'n Christelike mensbeskouing ons nie by die skeppingsleer kan bly vassteek nie, maar die Christologie en pneumatologie ook deeglik in berekening moet bring. Daar kan moeilik aanvaar word dat "hierdie eienaardige teologie", hierdie ordenings- en voorsienigheidsteologie, lewensvatbaar sal wees, want daarvoor is die Skrifuurlike basis te karig en te twyfelagtig en die Christologie te afwesig (Durand, 1982:197).

\subsubsection{Samevattend}

Dit is bemoedigend dat buitestanders positiewe oordele oor die GKSA uitspreek. Beyers Naudé (1985:172-173) merk byvoorbeeld op dat van die drie Afrikaanse kerke probeer die Gereformeerde Kerke "het meest serieus de waarheid van het Evangelie ten opzichte van de rassenverhoudingen en mensenrechten te laten doorklinken"; Durand (1985:50) stel dat "especially in the academic and theological circles of Potchefstroom and the Reformed Church (Gereformeerde Kerk) 
the shift from an apartheid theology to a less apartheid-orientated and more critical theology is evident"; en W.A. de Klerk (1976:342) konstateer dat in Potchefstroom "probably more of the original Calvin has survived than anywhere else". Waarskynlik is hierdie uitsprake meer gerig op die Afrikaanse Calvinistiese Beweging (later genoem die Reformatoriese Beweging van Suider-Afrika), met sy lyfblad Woord en Daad, as op die GKSA. Hierdie uitsprake sou totaal verkeerd verstaan word indien iemand daaruit sou aflei dat binne die GKSA alles uitgesorteer en volkome duidelik is en dat daar geen meningsverskil en selfs spanning bestaan nie. Wat wél waar is, is dat daar inderdaad 'n meer kritiese verantwoording ten opsigte van die apartheidsideologie voltrek word. Die tyd is in elk geval finaal verby dat slegs blanke Christene hulle met hierdie vrae mag besig hou. As ons nie die pad van die sektewese wil opgaan nie, sal ons voortaan sáám met die swart Christene oor kerk en ekumene, oor volk en vaderland, oor vryheid en geregtigheid moet besin. Die waarheid word sáám gevind (Ef. 3:10) en sáám gedien. Besinning oor hierdie vraagstukke hoort tuis op algemene en ekumeniese sinodes. 